\title{
Magnitude-frequency of sea cliff instabilities
}

\author{
F. M. S. F. Marques \\ University of Lisbon, Faculty of Sciences, Department of Geology and Centre of Geology, Portugal \\ Received: 8 January 2008 - Revised: 6 September 2008 - Accepted: 6 September 2008 - Published: 22 October 2008
}

\begin{abstract}
The magnitude-frequency relationship of sea cliff failures in strong, low retreat rate cliffs, was studied using systematic historical inventories carried out in the coasts of Portugal and Morocco, in different geological and geomorphological settings, covering a wide size scale, from small to comparatively large rockslides, topples and rockfalls, at different time and spatial scales. The magnitude-frequency expressed in terms of volume displaced and of horizontal area lost at the cliff top showed good fit by inverse power laws of the type $p=a . x^{-b}$, with $a$ values from 0.2 to 0.3 , and exponents $b$ close to 1.0 , similar to those proposed for rockfall inventories. The proposed power laws address the magnitudefrequency for sea cliff failures, which is an important component of hazard assessment, to be completed with adequate models for space and time hazard components. Maximum local retreat at the cliff top provided acceptable fitting to inverse power laws only for failures wider than $2 \mathrm{~m}$, with $a=4.0$, and exponent $b=2.3$, which may be useful to assess the cliff retreat hazard for the use of areas located near the cliff top.
\end{abstract}

\section{Introduction}

Landslide hazard assessment involves the determination of the location and timing of occurrence of landslides (Varnes, 1984), and also the magnitude or intensity of the potentially hazardous phenomena (Guzzetti et al., 1999, 2005).

The problem of the relations between magnitude and frequency of the landslides has been covered in the literature, mainly by analysis of landslide inventory data sets obtained in specific geomorphological contexts and triggered by single external factors such as heavy rainfall events, sudden snowmelt, earthquakes, or a combination of triggering fac-

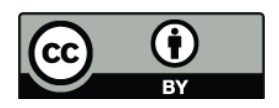

Correspondence to: F. M. S. F. Marques (fsmarques@fc.ul.pt) tors in historical inventory data sets. The magnitude of the landslides was mainly expressed in terms of the area affected by each event, which is the most easily measurable quantity, and in a few cases by the volume of soil and rock displaced, which is much more difficult to assess. The analyses of the inventory data sets yielded relationships between magnitude expressed as landslide area and frequency in the form of inverse power-law (Hovius et al., 1997, 2000; Pelletier et al., 1997; Dai and Lee, 2001; Guzzetti et al., 2002; Iwahashi et al., 2003; Brardinoni and Church, 2004). The recognition of a frequency reduction for the smaller landslides in substantially complete inventories led to the application of more accurate statistical distributions such as the inverse double Pareto (Stark and Hovius, 2001) and inverse Gamma 3 parameters (Malamud et al., 2004).

The magnitude-frequency relationships for rockfalls are less covered (Hungr et al., 1999; Dussauge-Peisser et al., 2002; Chau et al., 2003) and the on particular context of sea cliffs the available information is even more limited. In fact, most sea cliff studies are directed to yield coastal erosion dedicated data, such as retreat rates, dominantly in soft materials cliffs with intermediate to high retreat rates, and not inventories of cliff instabilities (see for ex. Lee et al., 2001, 2002; Hall et al., 2002; Moore and Griggs, 2002).

For soft cliff retreat, Hall et al. (2002) suggested a lognormal frequency-size distribution based on wave basin tests on a model cliff composed by damp sand, acted upon short term wave action. However, Dong and Guzzetti (2005) suggested that the distribution of erosion sizes (local retreat at the cliff top) between monitoring periods at two soft cliff sites in the east coast of England, follows a inverse power law for retreat events larger than $8 \mathrm{~m}$, and a much lower slope trend for smaller retreat events. These authors also pointed out that the data used corresponds to cliff top retreat values averaged for the length of the time periods elapsed between successive surveys, and, in consequence the data may present some form of amalgamation, i.e., measurements

Published by Copernicus Publications on behalf of the European Geosciences Union. 
Table 1. Summary data on the cliff instability inventories used in this study.

\begin{tabular}{|c|c|c|c|c|c|c|c|c|c|c|}
\hline \multirow[t]{2}{*}{ Cliffed coast } & \multirow[t]{2}{*}{ Age } & \multirow[t]{2}{*}{ Lithology } & \multirow[t]{2}{*}{ Structural features } & \multirow{2}{*}{$\begin{array}{l}\text { Length of } \\
\text { cliffs } \\
(\mathrm{km})\end{array}$} & \multirow{2}{*}{$\begin{array}{l}\text { Number } \\
\text { of cliff } \\
\text { failures }\end{array}$} & \multirow{2}{*}{$\begin{array}{l}\text { Monitoring } \\
\text { period/method }\end{array}$} & \multicolumn{3}{|c|}{ Cliff retreat rates (m/year) } & \multirow{2}{*}{$\begin{array}{l}\text { Details } \\
\text { (References) }\end{array}$} \\
\hline & & & & & & & $\begin{array}{l}\text { Mean } \\
\text { (m/year) }\end{array}$ & $\begin{array}{l}\text { Maximum } \\
(\mathrm{m} / \text { year })\end{array}$ & $\begin{array}{l}\text { Minimum } \\
\text { (m/year) }\end{array}$ & \\
\hline $\begin{array}{l}\text { Miocene } \\
\text { South Algarve }\end{array}$ & Miocene & Weak calcarenites & $\begin{array}{l}\text { Near horizontal beds, } \\
\text { massive rock mass, } \\
\text { extensive karst features } \\
\text { (sinkholes) }\end{array}$ & 46 & 147 & $\begin{array}{l}\text { 1947-1991 } \\
\text { Aerial photos }\end{array}$ & 0.006 & 0.039 & 0.002 & $\begin{array}{l}\text { Marques (1994) } \\
\text { Marques (1997) }\end{array}$ \\
\hline $\begin{array}{l}\text { Mesozoic } \\
\text { South and West Algarve }\end{array}$ & $\begin{array}{l}\text { Jurassic, Lower } \\
\text { Cretaceous }\end{array}$ & $\begin{array}{l}\text { Marly limestones, marls, } \\
\text { limestones }\end{array}$ & $\begin{array}{l}\text { Near horizontal beds, } \\
\text { faulted }\end{array}$ & 41 & 87 & $\begin{array}{l}\text { 1947-1991 } \\
\text { Aerial photos }\end{array}$ & 0.003 & 0.016 & $<0.001$ & Marques (1997) \\
\hline $\begin{array}{l}\text { Palaeozoic } \\
\text { West Algarve }\end{array}$ & Carboniferous & $\begin{array}{l}\text { Alternating shale and } \\
\text { greywacke }\end{array}$ & Highly folded anf faulted & 48 & 45 & $\begin{array}{l}\text { 1947-1991 } \\
\text { Aerial photos }\end{array}$ & 0.004 & 0.017 & 0.003 & $\begin{array}{l}\text { Marques (1997) } \\
\text { Marques (2003) }\end{array}$ \\
\hline $\begin{array}{l}\text { Cemented dunes } \\
\text { West Algarve }\end{array}$ & Quaternary & $\begin{array}{l}\text { Weak sandstone } \\
\text { (aeolianite) }\end{array}$ & $\begin{array}{l}\text { Massive, near horizontal } \\
\text { beds }\end{array}$ & 2.2 & 12 & $\begin{array}{l}\text { 1947-1991 } \\
\text { Aerial photos }\end{array}$ & 0.019 & 0.028 & 0.006 & Marques (1997) \\
\hline Larache - NW Morocco & $\begin{array}{l}\text { Quaternary over } \\
\text { Miocene }\end{array}$ & $\begin{array}{l}\text { Weak sandstone } \\
\text { (aeolianite) over clays }\end{array}$ & $\begin{array}{l}\text { Massive, near horizontal } \\
\text { beds }\end{array}$ & 5.5 & 37 & $\begin{array}{l}\text { 1961-1997 } \\
\text { Aerial photos }\end{array}$ & 0.016 & 0.088 & 0.006 & Marques et al. (2003) \\
\hline $\begin{array}{l}\text { Monte Clérigo } \\
\text { West Algarve }\end{array}$ & Carboniferous & $\begin{array}{l}\text { Alternating shale and } \\
\text { greywacke }\end{array}$ & $\begin{array}{l}\text { Highly folded and } \\
\text { faulted }\end{array}$ & 1.3 & 14 & $\begin{array}{l}\text { 1947-2000 } \\
\text { Aerial photos }\end{array}$ & 0.008 & 0.014 & 0.006 & Marques (2006b) \\
\hline $\begin{array}{l}\text { Avencas-Parede } \\
\text { West lisbon }\end{array}$ & Cenomanian & $\begin{array}{l}\text { Alternating marls and } \\
\text { marly limestones }\end{array}$ & $\begin{array}{l}\text { Near horizontal beds, } \\
\text { faulted }\end{array}$ & 2.6 & 10 & $\begin{array}{l}\text { 1947-2000 } \\
\text { Aerial photos }\end{array}$ & 0.001 & N.D. & N.D. & Marques (2006b) \\
\hline $\begin{array}{l}\text { Ribeira de Ilhas } \\
\text { NW Lisbon }\end{array}$ & Lower Cretaceous & $\begin{array}{l}\text { Alternating marls and } \\
\text { marly limestones }\end{array}$ & $\begin{array}{l}\text { Near horizontal beds, } \\
\text { faulted }\end{array}$ & 4.7 & 30 & $\begin{array}{l}\text { 1947-2000 } \\
\text { Aerial photos }\end{array}$ & 0.003 & 0.013 & 0.005 & Marques (2006b) \\
\hline $\begin{array}{l}\text { Monte Clérigo } \\
\text { West Algarve }\end{array}$ & Carboniferous & $\begin{array}{l}\text { Alternating shale and } \\
\text { greywacke }\end{array}$ & $\begin{array}{l}\text { Highly folded and } \\
\text { faulted }\end{array}$ & 0.22 & 20 & $\begin{array}{l}\text { 1999-2003 } \\
\text { Field photos }\end{array}$ & 0.004 & N.D. & N.D. & Marques (2006b) \\
\hline $\begin{array}{l}\text { Avencas-Parede } \\
\text { West lisbon }\end{array}$ & Cenomanian & $\begin{array}{l}\text { Alternating marls and } \\
\text { marly limestones }\end{array}$ & $\begin{array}{l}\text { Near horizontal beds, } \\
\text { faulted }\end{array}$ & 0.11 & 25 & $\begin{array}{l}\text { 1999-2003 } \\
\text { Field photos }\end{array}$ & 0.017 & N.D. & N.D. & Marques (2006b) \\
\hline $\begin{array}{l}\text { Ribeira de Ilhas } \\
\text { NW Lisbon }\end{array}$ & Lower Cretaceous & $\begin{array}{l}\text { Alternating marls and } \\
\text { marly limestones }\end{array}$ & $\begin{array}{l}\text { Near horizontal beds, } \\
\text { faulted }\end{array}$ & 0.24 & 103 & $\begin{array}{l}\text { 1999-2003 } \\
\text { Field photos }\end{array}$ & 0.008 & N.D. & N.D. & Marques (2006b) \\
\hline $\begin{array}{l}\text { Miocene field } \\
\text { South Algarve }\end{array}$ & Miocene & Weak calcarenite & $\begin{array}{l}\text { Near horizontal beds, } \\
\text { massive rock mass, } \\
\text { extensive karst features } \\
\text { (sinkholes) }\end{array}$ & 46 & 133 & $\begin{array}{l}\text { 1995-2004 } \\
\text { Field surveys }\end{array}$ & 0.009 & N.D. & N.D. & Teixeira (2006) \\
\hline
\end{tabular}

may represent single or multiple cliff retreat events (Dong and Guzzetti, 2005). This could cause a significant undersampling of the smaller cliff retreat movements, yielding frequency-size statistics following different power-laws for larger and smaller cliff retreat events.

In intermediate to high strength sea cliff rock masses, the retreat data expressed in terms of systematic and detailed inventory of cliff failures is even rarer, with very few exceptions (Marques, 1994, 1997, 2003, 2006b; Teixeira, 2006). However, sea cliff instability hazard assessment is a relevant topic because cliff dominated coasts have a very wide representation in the world coastlines, and in many countries, are subject to an intense and growing human occupation, mainly by houses, urban areas, and beach and leisure structures mainly devoted to tourism activities. The exploitation of these structures is very sensitive to safety issues, with natural hazards prevention and protection being a considerable concern. There is also considerable historical (mainly defence structures) and archaeological heritage located on top of sea cliffs, involving problems for their conservation.

The magnitude of the sea cliff instabilities, mainly planar slides, toppling failures and rockfalls, can be expressed by the local maximum retreat at the cliff top, horizontal area lost and volume displaced, that have implications on management and hazard prevention regulations of cliff top occupation and use (set back lines based on maximum local retreat and horizontal area lost at the cliff top), for use of the areas near the cliff toe (beaches, coastal infrastructures) and design of preventive or stabilization measures (cliff instability type and volume).

To address the magnitude-frequency relationships of sea cliff failures in strong, low retreat rate cliffs (mean retreat rate $<0.1 \mathrm{~m} /$ year), were used systematic historical inventories carried out in Portugal and in the north-west coast of Morocco, in different geological and geomorphological settings, in terms of volume of rock or soil displaced $\left(\mathrm{V}_{\mathrm{CR}}\right)$, of horizontal area lost at the cliff top $\left(\mathrm{A}_{\mathrm{CR}}\right)$ and of maximum local retreat of the cliff top $\left(M L R_{C R}\right)$. The inventories cover a very wide size scale of the cliff retreat phenomena, from small $\left(\mathrm{V}<0.01 \mathrm{~m}^{3}\right)$ to comparatively large rockslides, topples and rockfalls $\left(\mathrm{V}>10^{4} \mathrm{~m}^{3}\right)$, to large translational slides and a few cave roof collapses, at different time and spatial scales. The methods used for identification and characterization of the slope mass movements that occurred at the sea cliffs, cover complementary and partially overlapping size windows, in order to minimize the under sampling that results from the application of aerial photographs based methods near their lower limit of detection of the cliff retreat phenomena.

Deep seated landslides are excluded in this analysis mainly because they are extremely rare events in the geological and climatic context of the cliffs in Portugal and Morocco, and only occur in very special conditions, not related with the 
occurrence of the smaller and much more frequent cliff failures types indicated above.

\section{Study areas}

The data sets used in this study correspond to cliff retreat surveys carried at a regional scale, covering long stretches of cliffed coast, and local scale surveys. The data sets include only data for cliffs with mean retreat rates lower than $0.1 \mathrm{~m} /$ year, i.e. cliffs where a large part of the cliff top remain essentially unchanged at the time scale of half a century, and the retreat is caused by the occurrence of cliff failures with local impact.

The regional scale data sets (Table 1, Fig. 1) cover the whole rock cliffs of the western and southern coast of Algarve, divided according to the main geological units, which include weak Miocene calcarenites, Carboniferous shale and greywacke, Mesozoic marls and limestones and Quaternary cemented dunes. Were also used data sets from cliffs cut in Cretaceous rocks located at West (Avencas-Parede, AP) and Northwest (Ribeira de Ilhas, RI) of Lisbon, and from the Quaternary cemented dunes underlain by clays in the west coast of Morocco (Larache). It is also included the systematic field survey based inventory of cliff instabilities that occurred in the Miocene cliffs of the central Algarve coast (Teixeira, 2006).

The local scale data sets (Table 1, Fig. 1) correspond to two cliff faces composed of Cretaceous of near horizontal alternating marls and limestones (Avencas-Parede, AP, and Ribeira de Ilhas, RI) and one data set for a cliff face cut in highly folded and faulted Carboniferous shale and greywacke (Monte Clérigo, MC).

For the central Algarve coastal cliffs cut in Miocene rocks, details on the geomorphology, types, and spatial and time distribution of cliff retreat events identified and measured on aerial photographs of 1947 and 1983 are in Marques (1994). The retreat data was completed for the 1947 to 1991 period, together with detailed geomorphological analysis and rock strength assessment (Marques, 1997), and further details on cliff morphology and recent movements are described in Teixeira (2006). These cliff sections extend for approximately $46 \mathrm{~km}$ and are mainly cut in weak biogenic calcarenites of Miocene age (Antunes et al., 1981), with horizontal or gently sloping bedding to south or southwest except near the main tectonic accidents (Portimão fault and Albufeira diapir) were bedding slope can reach $10^{\circ}$ to $20^{\circ}$. The Miocene bedrock is densely affected by karst features, which are mainly $6 \mathrm{~m}$ to $20 \mathrm{~m}$ wide near circular section sinkholes with walls cemented by secondary calcite precipitation, and is covered by Plio-pleistocene reddish siltyclayey sands, which also fill the karst features. The contrasts of strength and erosion resistance of the materials that compose the cliffs, and also the karst exhumation by marine ero-

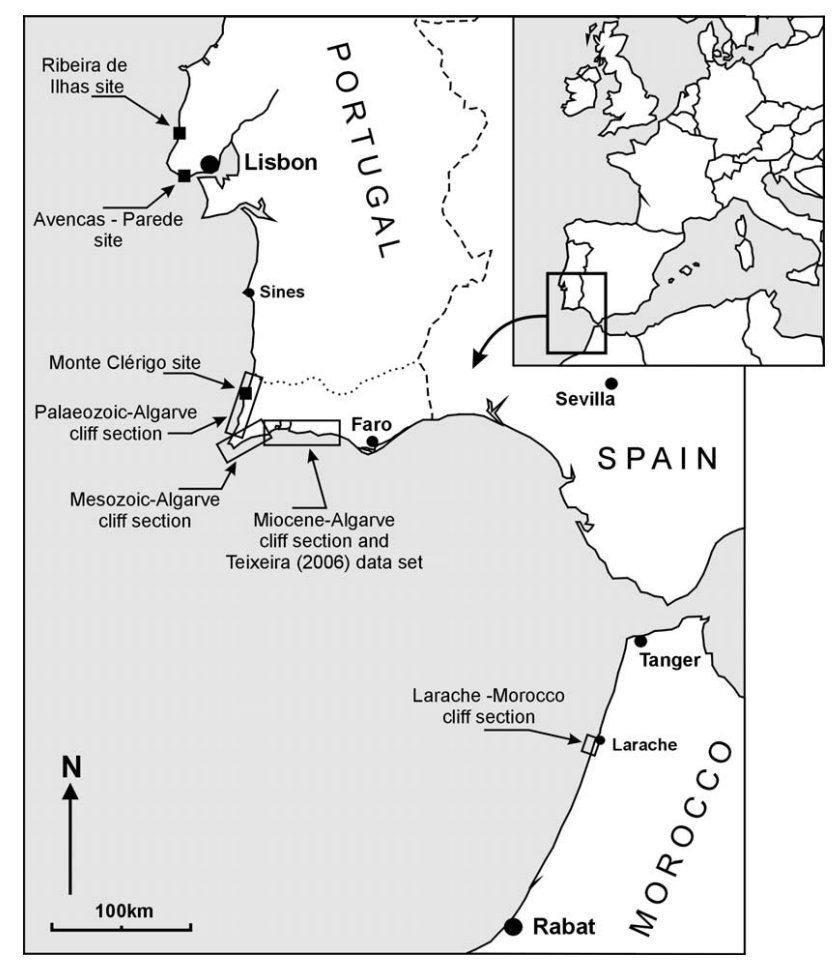

Fig. 1. Location of the cliff sections studied along the western and southern coast of Portugal, and along the north west coast of Morocco.

sion are the main causes of the very complex morphology of the coastline.

The Miocene rocks are mainly composed by alternate layers of fine grained calcarenites and calcarenites with a high content of macrofossils. The latter are more resistant to surficial erosion and tend to protrude outwards of the cliff profiles not recently affected by cliff retreat.

In terms of geotechnical properties the fine-grained calcarenites have saturated unconfined compressive strength between $0.5 \mathrm{MPa}$ and $2 \mathrm{MPa}$, calcarenites with macrofossils from $1 \mathrm{MPa}$ to $3 \mathrm{MPa}$. Locally, the presence of secondary precipitations of calcite provides values of up to $50 \mathrm{MPa}$. Fracture surfaces are very rough and, in consequence, conditions for the occurrence of planar slides are seldom attained, and the bedding planes are not sharp discontinuities but gradual transitions of the texture of the rock. The natural discontinuities are also partially cemented by secondary calcite precipitations, providing a massive behaviour of the rock mass, with small contribution of the tectonic fractures and the bedding planes for the occurrence of cliff failures.

The cliffs have a complex plan contour, which includes frequent headlands with plunging cliffs separated by generally small bays that contain sandy beaches. Discontinuous shore platforms, stacks, caves and natural arches and bridges are also very frequent features. The cliffs height varies between extreme values of $2 \mathrm{~m}$ to $40 \mathrm{~m}$, with predominant height between $15 \mathrm{~m}$ and $25 \mathrm{~m}$. 
In terms of processes and mechanisms of cliff retreat, the marine erosion is responsible for the carving of notches mainly at the upper intertidal zone and the rapid erosion of the sandy karst fill. In consequence, the cliff profiles in the Miocene rocks are generally irregular, near vertical and with a notch at the toe. The deepening of the notches coupled with the stress release of the rock mass leads to toppling failures that are the most frequent mass movements in these cliffs $(42 \%)$, followed by rockfalls (18\%), very rare slumps (4\%) and not determined type (36\%, mainly rockfalls and small topples) (Marques, 1997).

The western coast of Algarve is dominated by sea cliffs (Fig. 1) (Marques, 2003) mainly composed of an Upper Palaeozoic sequence, with minor sections of Mesozoic carbonate rocks, Triassic sandstones, Hetangian Keuper marls and Quaternary cemented dunes. The Palaeozoic rocks are included in the western border of the South Portuguese Zone, a part of the south west branch of the Iberian Variscan Arc that includes an Upper Devonian basement and the condensed facies of the Bordeira anticline, overlain by a Carboniferous flysh sequence - the Brejeira Formation, (Ribeiro et al., 1987).

The general sequence includes the Bordeira-Carrapateira Formations (Ribeiro et al., 1987) exposed in small sections at the sea cliffs and includes dark grey shales alternating with sandstones and dolomitic limestones, overlain by the Brejeira Formation (Carboniferous, Middle Namurian to Lower Westphalian) that forms the majority of the cliffs in the study area. This hercinian flysch deposit is mainly composed of dark grey shales alternating with generally thin sandstone beds. The Paleozoic rocks were folded and faulted by the Hercynian Orogeny and the alternating layers of shale and greywacke are affected by NW-SE trending folds with an axial plane cleavage dipping NE. The highly folded structure and the irregular contour of the cliffs make the relations between strata orientation and cliff faces extremely variable from site to site.

The sea cliffs are mainly $40 \mathrm{~m}$ to $100 \mathrm{~m}$ high, with maximum height of $120 \mathrm{~m}$. The cliffs profile is very irregular and varies from place to place, mainly as a consequence of the heavily folded and faulted geological structure and the varying erosion resistance of the Palaeozoic rocks. The cliff toe is usually seawards limited by intertidal abrasion platforms, frequently seawards limited by a low tide scarp, locally covered by small gravel beaches and rare sand beaches. Near vertical cliff faces that plunge directly below sea water level (plunging cliffs), indicating very low cliff retreat during Holocene, occur only in small sections.

In terms of geotechnical properties, point load tests on fresh to slightly weathered greywacke sandstones and muddy quartzites with average dry unit weights of $26.3 \mathrm{kN} / \mathrm{m}^{3}$ yielded $I s_{(50)}$ values between $1 \mathrm{MPa}$ and $10 \mathrm{MPa}$. The unweathered shales have an average dry unit weight of $26.5 \mathrm{kN} / \mathrm{m}^{3}$ and point load strengths from 0.5 to $1.5 \mathrm{MPa}$ parallel to bedding and between $1 \mathrm{MPa}$ and $3 \mathrm{MPa}$ at right angles to the bedding planes. Small scale field tilt tests produced friction angles between $27^{\circ}$ and $34^{\circ}$, greater than the residual friction angle for these rocks, mainly because of the roughness of the specimen tested and the low confining stresses. The back analysis of major failures provided friction angles from $23^{\circ}$ to $25^{\circ}$ (Marques, 2003).

The planar (translaccional) failures were dominant in the palaeozoic rock cliffs, accounting for $85 \%$ of the total movements identified, with minor occurrences of toppling and toppling followed by planar failure, and one case of buckling and another case not determined.

Monte Clérigo site is located in the palaeozoic cliff section of the west coast of the Algarve (Fig. 1). It is a high energy WNW exposed $40 \mathrm{~m}$ high cliff, seawards limited by a 80 to $100 \mathrm{~m}$ wide shore platform. Cliff and platform are cut in lowmetamorphic Carboniferous rocks, composed of alternating dark grey shale and generally thin sandstone and greywacke beds. The cliff face varies from near vertical to $45^{\circ}$ sloping irregular profiles, usually limited at the toe by near vertical sections caused by direct marine erosion. Bed thickness is quite variable between $2 \mathrm{~cm}$ and $20 \mathrm{~cm}$ and there is a net dominance of shale thickness (c. 65\%) over greywacke (35\%). Cliff failures identified are mainly of the planar type.

The Mesozoic rock cliffs of Algarve include the western section of the south coast and a small section at the west coast that corresponds to the Carrapateira headland. In the southern coast, from east to west, cliffs are composed of horizontal or SE gently sloping alternating layers of marls and marly limestones (Lower Cretaceous; $3.7 \mathrm{~km}$ of cliff length), marls (Lower Cretaceous, $0.3 \mathrm{~km}$ of cliff length), SE $10^{\circ}$ to $15^{\circ}$ dipping strong sandstones (Lower Cretaceous, $2 \mathrm{~km}$ of cliffs), nearly horizontal or SE gently dipping alternating marls and marly limestones (Lower Cretaceous, $6.1 \mathrm{~km}$ of cliffs), alternating marls and marly limestones and limestones (Upper Jurassic, $3.7 \mathrm{~km}$ of cliffs) and $27.4 \mathrm{~km}$ of cliffs mainly cut in strong limestones and very strong dolomites that form the main headlands in the area (Jurassic), with minor occurrence of marly sequences outcropping at the more recessed portions of the coastline (Rocha et al., 1979; Marques, 1997).

At the Carrapateira headland (west coast of Algarve), the sea cliffs are cut, from south to north, in alternating marls and limestones (Jurassic, $3.2 \mathrm{~km}$ of cliffs) and limestones (Jurassic, $1.6 \mathrm{~km}$ of cliffs), mostly with near horizontal bedding (Ribeiro et al., 1987; Marques, 1997).

Cliff height varies mainly between $30 \mathrm{~m}$ and $60 \mathrm{~m}$, reaching locally maximum values of $110 \mathrm{~m}$. Cliff profiles are quite variable and range from near vertical plunging rock walls at the main headlands cut in the strong Jurassic limestones and dolomites, to $45^{\circ}$ to $60^{\circ}$ slope sections in the cliffs cut in the weaker marls and alternating marls and limestones. In these weaker rocks, there is usually an intertidal shore platform that generally dips gently seawards without any low tide scarp. 
The cliff failures identified correspond to planar slides (77\%), rockfalls (16\%) and not determined type (7\%).

Avencas-Parede is located on a sheltered NW-SE section (Fig. 1) of an E-W trending coast located westwards of Lisbon. It is a low-energy rocky coast cut in near horizontal beds of Middle (Albian sandstones) and Upper Cretaceous (Albian-Cenomanian marly nodular limestones and limestones alternating with marls), cut by minor NNE-SSW, $\mathrm{N}-\mathrm{S}$ and WNW-ESE faults, some containing igneous dykes (Ramalho et al., 1981). The cliffs are 4 to $15 \mathrm{~m}$ high, and are limited seawards by mainly structurally controlled shore platforms and sand beaches in the more sheltered bays. At the Praia das Avencas site, the cliffs are 4 to $6 \mathrm{~m}$ high and are seawards limited by a $80 \mathrm{~m}$ wide structurally controlled wave cut platform with steps that correspond to the outcrops of the more resistant limestone beds. The cliff is composed of a single bed of marly nodular limestone (70\% marly limestone; $30 \%$ marl), with an irregular and near vertical surface with a $0.3 \mathrm{~m}$ to $0.5 \mathrm{~m}$ deep notch at the toe. The cliff retreat events correspond to planar, toppling and rockfall failures (Marques, 2006b).

Ribeira de Ilhas cliff section is located on the west coast $40 \mathrm{~km}$ north of Lisbon. It is a high energy coast, dominated by $15 \mathrm{~m}$ to $30 \mathrm{~m}$ high cliffs, which reach $60 \mathrm{~m}$ height south of the RI site. The cliffs are composed of near horizontal Lower Cretaceous (Hauterivian to Aptian) alternating limestones and marly limestones (Hauterivian-Lower Barremian), sandstones (Upper Barremian) and alternating limestones and marls (Lower Aptian), and are cut by faults and dykes trending E-W, NE-SW and NW-SE (Zbyszewski and Almeida, 1955).

At the Ribeira de Ihas site, the 25 to $30 \mathrm{~m}$ high cliff is cut in near horizontal alternating layers of marly limestones $(0.2-$ $1.0 \mathrm{~m}$ thick), marls (0.5-2 m thick) and two sandstone beds in the upper part, cut by minor faults and three dykes. In the lower part of the cliff marly limestones dominate, while in the middle and upper parts, marls are the main lithology. The cliff is limited by an 80 to $100 \mathrm{~m}$ wide wave cut platform, stepped at the upper intertidal zone but very smooth seawards. The cliff toe is partially covered by fallen blocks from the cliff and, during the summer, by thin ephemeral patches of gravel and coarse sand.

The lower part of the cliff profile is near vertical with frequent overhangs of the more resistant limestone beds, and an upper third section sloping $45^{\circ}$ to $60^{\circ}$ seaward, that corresponds to the more weathered upper part of the rock mass (sandstones, limestones and marls). The cliff retreat events identified correspond also to planar, toppling and rockfall failures, as in Avencas-Parede coastal section (Marques, 2006b).

At the NW coast of Morocco, the Larache near vertical cliffs have heights between $10 \mathrm{~m}$ and more than $20 \mathrm{~m}$, and are composed by weak to moderately strong Quaternary massively bedded cemented dunes, cut by generally widely spaced joints. This unit is affected by karst features which are partially filled by reddish sandy clayey deposits. The cemented dunes rest over low strength Miocene-Pliocene clays. Cliff retreat events correspond mainly to toppling failures (Marques et al., 2003).

The major cliff instability factors include rainfall, wave regime and earthquakes, and their action has strong variations along the coastal sections considered in this study.

The west coast of Portugal is attacked by a high-energy wave regime generated in the North Atlantic Ocean, with a predominant fetch (long swell) from the NW and storms from the W and SW (Pires, 1989). There is no information on the Larache coast of Morocco, but it is also exposed to WNW and in consequence, is probably acted by a wave regime with intensity not much lower than the ones of the western coast of Portugal. At the sheltered, southwest facing AP coast, the wave energy input drops by an order of magnitude, and the southern coast of Algarve is acted by storms from SW and SE, and a medium energy wave regime (Andrade et al., 2004).

Portugal is affected by considerable earthquake activity and during the cliff retreat survey periods, the sites were affected by the 28 February 1969 earthquake, with a Mercalli modified scale intensity of VIII at the SW coast of Algarve, $\mathrm{VI}$ at $\mathrm{AP}$ and VII at RI, and other smaller earthquakes with a maximum local intensity lower than VI (Anonymous, 19472003), usually not considered relevant in terms of slope instability triggering (Keefer, 1984). The coast of Larache was also affected by the 28 February 1969 earthquake (I=VI) and other earthquakes with smaller local intensity (El Alami et al., 2004).

Mean annual rainfall is also quite variable along the coast of Portugal, with a general tendency for decrease from north to south, with values of $778 \mathrm{~mm} \mathrm{y}^{-1}$ at the RI region, about $695 \mathrm{~mm} \mathrm{y}^{-1}$ at AP, $565 \mathrm{~mm} \mathrm{y}^{-1}$ at the western coast of Algarve (Aljezur station) and approximately $450 \mathrm{~mm} \mathrm{y}^{-1}$ at the southern coast of Algarve. Most of the rainfall occurs during the period October-May, usually concentrated in short periods, and this tendency tends to decrease slightly from south to north. At Larache coast, the mean annual rainfall is approximately $670 \mathrm{~mm} \mathrm{y}^{-1}$, also concentrated during the winter months and in short periods, typical of Mediterranean climate.

\section{Methods}

The regional scale data sets of sea cliff failures were produced using aerial photographs comparison for intermediate time (up to 53 years) for the identification and characterization of the larger cliff movements. The methods used rely on systematic comparison of pairs of the older and more recent photos, carried out with a table stereoscope with $8 \times$ magnification eyepieces, working in very small areas in order to detect changes in the cliff top contour. When a change is detected, intermediate date photos are used to constrain the 
period of occurrence and are selected the more favourable photos to perform the measurement of the maximum local cliff top retreat. The horizontal area lost at the cliff top is assessed dividing the total area in smaller simple polygons (triangles, rectangles), followed by the measurement of the dimensions required to compute the areas. The volume of rock and soil displaced in each retreat event was estimated considering the horizontal area lost and the estimated crosssectional dimensions of the failed rock mass obtained from aerial photo interpretation and fieldwork. The assessment of the volume of rocks displaced is computed based on the estimated depth and general slope of the failure surface visible at the cliff face, coupled with the altimetry collected in topographical maps. These inventories were subsequently object of a near systematic field checking. The measurements are performed directly on the aerial photo contact prints, using a transparent calibrated square grid with unit divisions of $0.083 \mathrm{~mm}$, which enables the measurement of distances down to half of division, i.e. $1.4 \mathrm{~m}$ in the field for 1:30000 scale photos. The measurements follow a set of procedures conceived to cope with the common problems involved in the use of aerial photos, namely relief displacement by conical projection and tilt, and to keep the measurement errors to less than $\pm 1.5 \mathrm{~m}$ in the field. The description of methods used and analysis of errors, based on the application of the colinearity equations of photogrammetry is treated in detail in Marques (2006a).

In terms of the accuracy of the methods used in cliff retreat assessment, the data set from the Miocene rock cliffs of Algarve had extensive field confirmation by the regional authority for coastal management (Teixeira, 2006), and the retreat of the soft cliffs of Quarteira region (Marques and Romariz, 1990; Marques and Andrade, 1993; Marques, 1997) have been confirmed by independent photogrammetry based studies (Correia et al., 1994; Catalão et al., 2002).

The local scale short-term cliff retreat data sets were assessed by sequential photographic field surveys of the cliff face, after emplacement of $2 \mathrm{~m}$ ruler scales at the base of the cliff. Pairs of stereoscopic photos were taken between 1999 and 2003 from fixed viewpoints using the same non-calibrated camera/lens combination (35 mm SLR with $55 \mathrm{~mm}$ focal length macro lens) and with the optical axis of the lens near horizontal. Oblique photo pairs of the cliff face were also taken to improve cliff retreat volume estimation together with field measurements.

The detection, dating, characterization and measurement of the cliff face area affected by the slope mass movements depicted in the stereoscopic pairs relied upon systematic checking of the morphology of each bed or group of beds outcropping along the cliff face, also performed under a table mirror stereoscope. The average thickness of the displaced blocks was assessed using the oblique pairs of photographs and field checking, and the volume of material displaced computed as the product of the area affected and the average thickness. Field photo survey accuracy depends on the scale of the photographs, and because each pair of photos must cover the whole cliff face it varies with cliff height. At AP resolution was higher and virtually all fallen rock blocks of near isometric shape larger than $0.006 \mathrm{~m}^{3}$ were detected. At RI the data should be considered complete for cliff rockfall volumes larger than $0.03 \mathrm{~m}^{3}$, while at MC the data can be considered complete for volumes larger than $0.2 \mathrm{~m}^{3}$.

The cliffs cut in the southern Algarve Miocene rocks were also object of a systematic cliff failure field based inventory, that was build by sequential and systematic field surveys coupled with a warning system network of coast users for the identification of cliff instabilities, carried out since 1995 by the Algarve regional authority for the environment (Comissão de Coordenação e Desenvolvimento Regional do Algarve, CCDRA; Teixeira, 2006).

The quality of the data in each data set is variable, covering maximum local retreat and horizontal area lost for each cliff retreat event in all inventories, and assessment of volume displaced in all but the inventory from Larache, Morocco, were only maximum local retreat and horizontal area lost were assessed due to the small scale of the available topographic maps.

For the coastal sections monitored by aerial photographs, the cliff retreat was computed using the slope of the best fit linear regression line of plots of cumulative horizontal area lost versus length of cliff, divided by the number of years of the study (Table 1). Values were computed for all data in each section, and maximum and minimum values were computed by the some process used data subsets with a nearly constant slope, that correspond to sub-sections with a nearly homogeneous behaviour in terms of cliff failures size and spatial density (see Marques, 2003, 2006b).

The computed cliff retreat rates (Table 1) are always lower than $0.1 \mathrm{~m} \mathrm{y}^{-1}$ and range for one order of magnitude, for mean values, and almost two orders of magnitude considering the maximum and minimum values. The computed values agree with the orders of magnitude of the retreat rates suggested by Sunamura (1992) for different rock types, that include flysh and shales $\left(10^{-2} \mathrm{~m} \mathrm{y}^{-1}\right)$, and limestones $\left(10^{-2} \mathrm{~m} \mathrm{y}^{-1}\right.$ to $\left.10^{-3} \mathrm{~m} \mathrm{y}^{-1}\right)$ ), which were based on a extensive world wide data compilation.

\section{Magnitude-frequency}

The natural hazards induced by sea cliff failures may affect structures or people located near the cliff top, at the exposed faces, which include accesses to the beaches, and the areas near the toe that may include beach users and support structures. Considering these different locations of potentially hazardous zones, the magnitude of the cliff retreat failures may be expressed in terms of three indexes: 1 . The maximum local retreat at the cliff top $\left(\mathrm{MLR}_{\mathrm{CR}}\right)$, measured as the maximum horizontal distance between the pre and post failure cliff top position, which is useful as a guide for the definition 


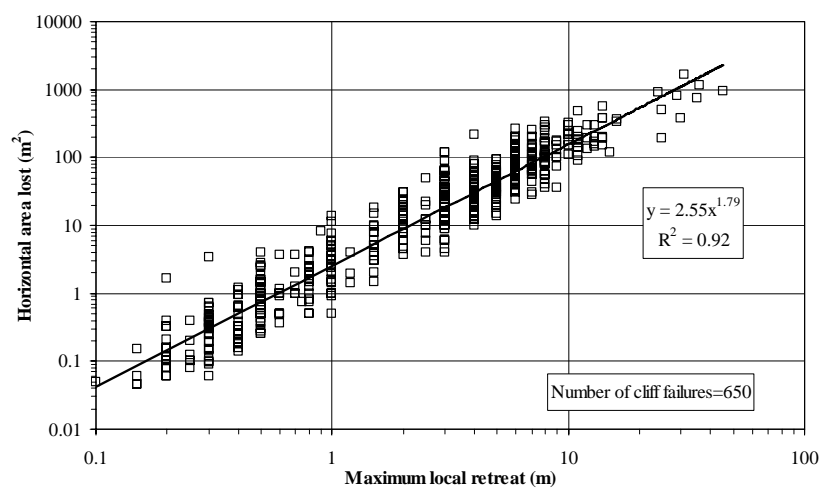

Fig. 2. Relation between maximum local retreat at the cliff top and horizontal area lost at the cliff top.

of set back or hazard lines near the cliff top. 2. The horizontal area lost $\left(\mathrm{A}_{\mathrm{CR}}\right)$ that corresponds to the horizontal cross section of the failed rock masses. 3. The volume of rocks displaced in each cliff retreat event $\left(\mathrm{V}_{\mathrm{CR}}\right)$, which is useful to assess the areas near the toe susceptible to be affected by cliff failures or to define cliff stabilization measures.

These magnitude indexes bear some relation between each other, mainly due to the types of failures identified, dominated by planar slides with steep sloping sliding surface, toppling failures and rockfalls. In fact, the maximum local retreat of the cliff top shows acceptable correlation with both the horizontal area lost (Fig. 2) and the volume displaced (Fig. 3), but with a considerable degree of data scatter, especially in the $\mathrm{MLR}_{\mathrm{CR}}-\mathrm{V}_{\mathrm{CR}}$ plot. The best fitting of the data plots was obtained with the power laws, $\mathrm{A}_{\mathrm{CR}}=2.55\left(\mathrm{MLR}_{\mathrm{CR}}\right)^{1.79}\left(r^{2}=0.92\right)$ and $\mathrm{V}_{\mathrm{CR}}=5.23$ $\left(\mathrm{MLR}_{\mathrm{CR}}\right)^{2.62}\left(r^{2}=0.88\right)$.

The horizontal area-volume relationship showed less data scatter and a good fitting (Fig. 4) by the power law relation $\mathrm{V}_{\mathrm{CR}}=1.37\left(\mathrm{~A}_{\mathrm{CR}}\right)^{1.46},\left(r^{2}=0.95\right)$ much different than those that have been suggested for inland landslides (e.g. Hovius et al., 1997). This is not surprising considering the differences in shapes, processes and mechanisms of mainland landslides, usually dominated by shallow translational slides, while the cliff failures are mainly steeply sloping failure surface planar slides, toppling failures and rock falls.

For cliff failure magnitude-frequency analysis, the movements smaller than the detection limits of the methods used for inventory production were removed in all data sets, and these are considered to be substantially complete for values above those limits (Table 2). The data was divided in magnitude (maximum local retreat, horizontal area lost and volume displaced) classes with the same width in logarithmic scale. As the results of the binning process are very sensitive to the class limits adopted, those limits were set up separately for each data set to insure an even distribution of cliff failures in each class. The classes with less than 3 events were merged with other adjacent low frequency classes, ensuring also that

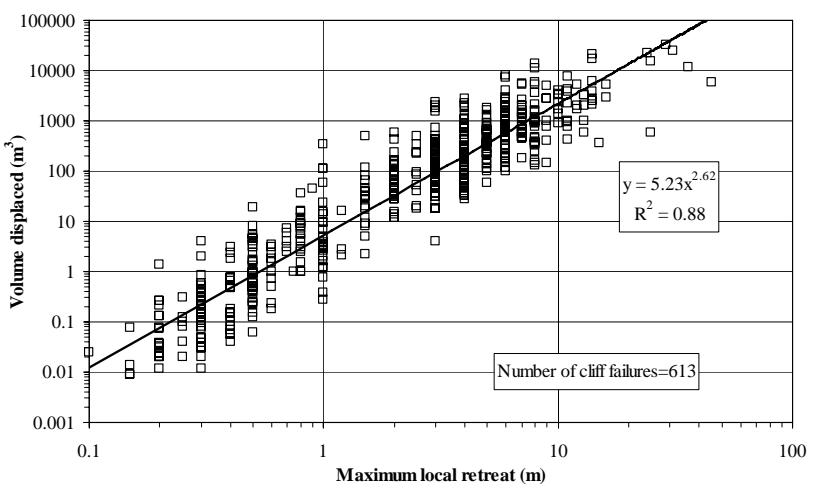

Fig. 3. Relation between maximum local retreat at the cliff top and volume displaced.

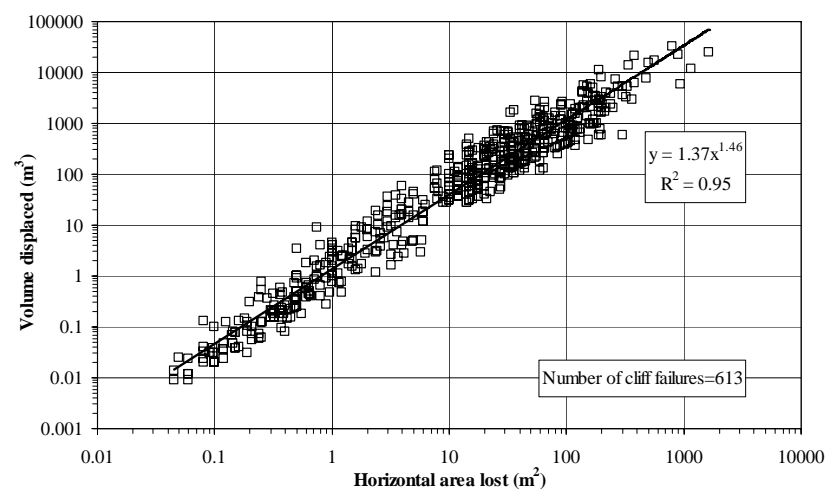

Fig. 4. Relation between horizontal area lost at the cliff top and volume displaced.

the event distribution in the new wider class was even, i.e. that the average size of the events contained in one class is near the mean value of the class limits.

The frequency density for maximum local cliff top retreat, $f\left(\mathrm{MLR}_{\mathrm{CR}}\right)$, horizontal area, $f\left(\mathrm{~A}_{\mathrm{CR}}\right)$ and for volume relationships $f\left(\mathrm{~V}_{\mathrm{CR}}\right)$, of each bin was computed as the number of cliff retreat failures in the bin divided by the bin width (Malamud et al., 2004). As the inventories are essentially complete above well defined size limits, it is acceptable to normalise the frequency densities by dividing them by the total number of events in each data set, obtaining normalised frequencies $p\left(\mathrm{MLR}_{\mathrm{CR}}\right), p\left(\mathrm{~A}_{\mathrm{CR}}\right)$ and $p\left(\mathrm{~V}_{\mathrm{CR}}\right)$.

For the maximum local cliff top retreat analysis, the only values considered were those that corresponded to a net retreat of the cliff top, and was excluded the data from movements that only affected the cliff face. Both the frequency density and the normalized frequency plots show a wide spread of data and a general concave downwards shape (Figs. 5 and 6). Reliable data fitting expressions were not found, suggesting that further work and more data is required to characterize this particular cliff retreat magnitude index. The larger than $2 \mathrm{~m}$ maximum local 
Table 2. Lower limits of magnitude data completeness for each data set.

\begin{tabular}{lccc}
\hline Cliffed coast & \multicolumn{3}{c}{ Lower limits of magnitude data completeness } \\
\hline & $\mathrm{MLR}_{\mathrm{CR}}(\mathrm{m})$ & $\mathrm{A}_{\mathrm{CR}}\left(\mathrm{m}^{2}\right)$ & $\mathrm{V}_{\mathrm{CR}}\left(\mathrm{m}^{3}\right)$ \\
\hline Miocene South Algarve & $2 \times 10^{0}$ & $10^{1}$ & $3 \times 10^{1}$ \\
Mesozoic South and West Algarve & $2 \times 10^{0}$ & $10^{1}$ & $7 \times 10^{1}$ \\
Palaeozoic West Algarve & $2 \times 10^{0}$ & $10^{1}$ & $3 \times 10^{1}$ \\
Cemented dunes West Algarve & $3 \times 10^{0}$ & $10^{1}$ & $3.5 \times 10^{1}$ \\
Larache - NW Morocco & $2 \times 10^{0}$ & $10^{1}$ & $\mathrm{~N} . \mathrm{D}$. \\
Monte Clérigo (aerial photos) West Algarve & $2 \times 10^{0}$ & $1.2 \times 10^{1}$ & $3 \times 10^{1}$ \\
Avencas-Parede (aerial photos) West lisbon & $3 \times 10^{0}$ & $6 \times 10^{0}$ & $10^{1}$ \\
Ribeira de Illhas (aerial photos) NW Lisbon & $2 \times 10^{0}$ & $9 \times 10^{0}$ & $3 \times 10^{1}$ \\
Monte Clérigo (field) West Algarve & N.A. & $5 \times 10^{-1}$ & $2 \times 10^{-1}$ \\
Avencas-Parede (field) West lisbon & N.A. & $5 \times 10^{-2}$ & $6 \times 10^{-3}$ \\
Ribeira de Illhas (field) NW Lisbon & N.A. & $8 \times 10^{-2}$ & $3 \times 10^{-2}$ \\
Miocene field South Algarve & $2 \times 10^{-1}$ & $10^{-1}$ & $2 \times 10^{-2}$ \\
\hline
\end{tabular}

N.D. - Not determined - Cliff failure volumes were not computed.

N.A. - Not applicable - Insufficient number of failures affecting the cliff top.

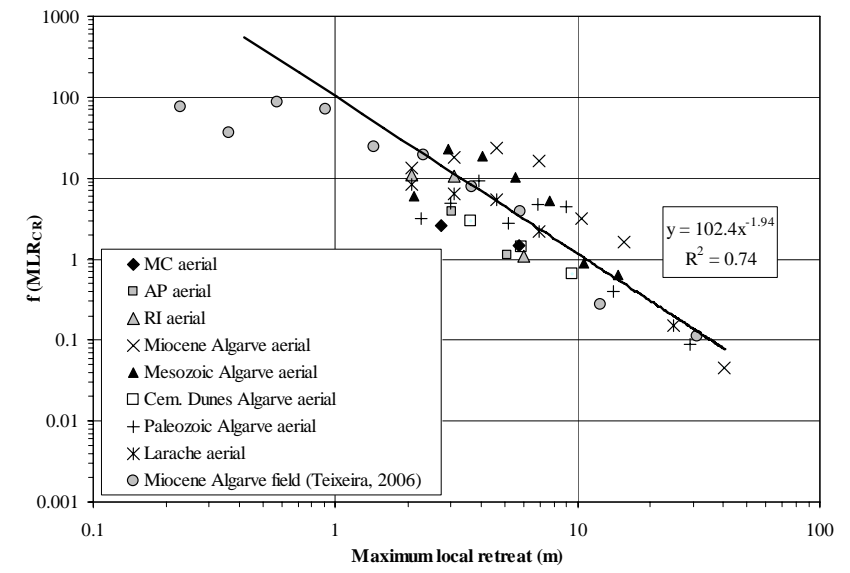

Fig. 5. Relation between maximum local retreat at the cliff top and the frequency density, with best fit inverse power law for movements with maximum local retreat higher than $2 \mathrm{~m}$.

retreat data may be approximately expressed by the preliminary power laws $f\left(\mathrm{MLR}_{\mathrm{CR}}\right)=102.4 x^{-1.94}\left(r^{2}=0.74\right)$ and $p\left(\right.$ MLR $\left._{\mathrm{CR}}\right)=3.98 x^{-2.30}\left(r^{2}=0.86\right)$.

The frequency densities of horizontal area lost and volume displaced showed comparatively less data spread and the data is aligned along similar negative slope lines in log-log plots (Figs. 7, 9). The normalized frequencies (Figs. 8, 10) show much smaller data spread and provided similar best-fit power laws with high correlation coefficients, $p\left(\mathrm{~A}_{\mathrm{CR}}\right)=0.29 x^{-1.08}$ $\left(r^{2}=0.92\right)$ and $p\left(\mathrm{~V}_{\mathrm{CR}}\right)=0.18 x^{-1.03}\left(r^{2}=0.96\right)$. The inverse power law exponents for frequency densities and normalized frequencies are almost constant and quite similar to the value proposed by Malamud et al. (2004)(Fig. 9) for three histori-

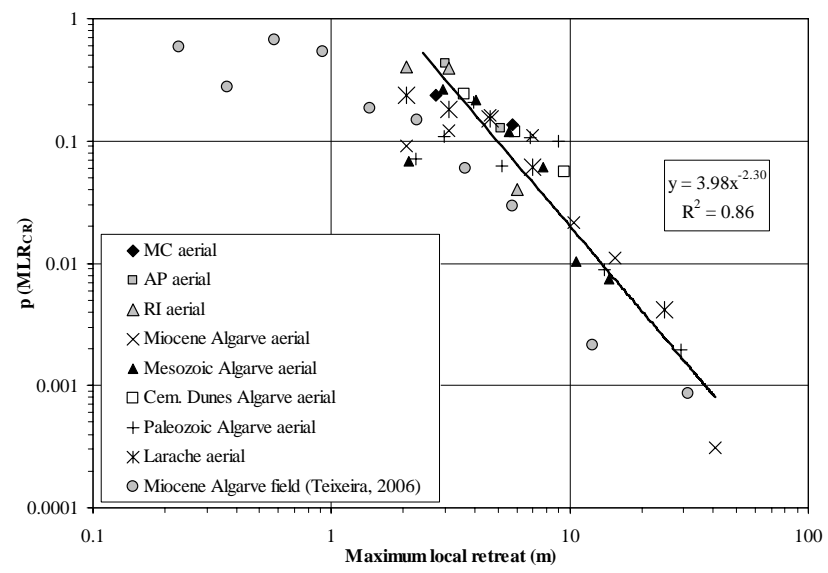

Fig. 6. Relation between maximum local retreat at the cliff top and the normalised frequency density, with best fit inverse power law for movements with maximum local retreat higher than $2 \mathrm{~m}$.

cal inventories of rockfalls. These magnitude-frequency relationships do not show any roll over of the power law towards the smaller movements as have been demonstrated for substantially complete landslide inventories (Stark and Hovius, 2001; Malamud et al., 2004). This indicates that the cliff retreat failures in conditions not favourable for the occurrence of deep-seated rotational landslides show a magnitudefrequency behaviour close to the available inventories of rock falls, suggesting close similarities in the processes involved in the instabilities of sea cliffs and other natural scarps.

The detailed analysis of the plots (Figs. 8, 10) shows a slight tendency for an increase of the slope of the data for the larger failures. This may be explained by an under sampling 


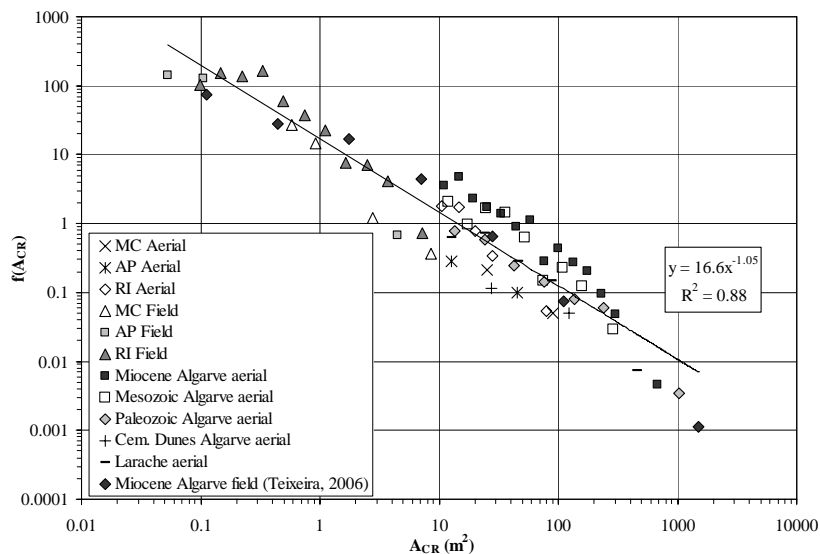

Fig. 7. Relation between horizontal area lost at the cliff top and the frequency density, with best fit inverse power law for all the data set.

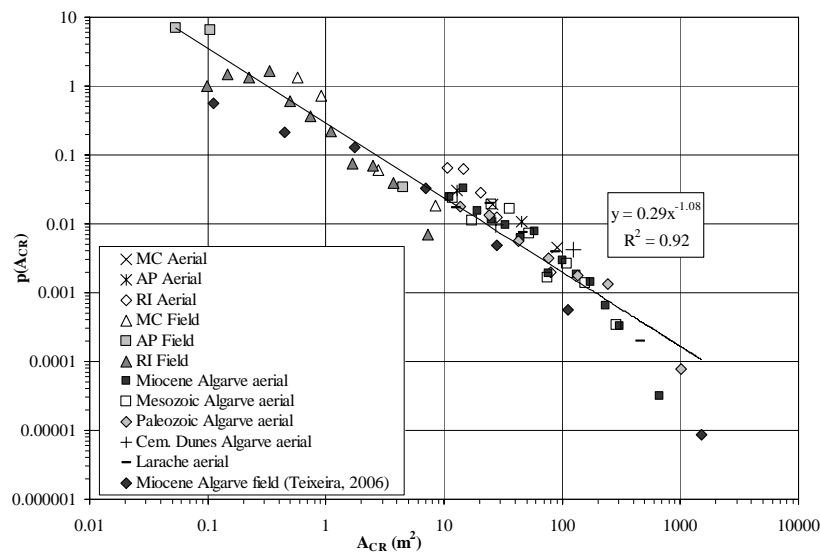

Fig. 8. Relation between horizontal area lost at the cliff top and the normalised frequency density, with best fit inverse power law for all the data set.

of the largest but least frequent events, due to the comparatively short time windows of monitoring, and also by the influence of an implicit upper size limit for cliff failures. In fact, for planar slides and rockfalls in cliffs where there are no conditions for the occurrence of deep seated landslides, the maximum local retreat, and to a lesser extent, the horizontal area lost and the volume displaced, depend mainly on cliff geometry (height and slope), and on the geotechnical properties of the rock masses that control the lower slope of the potential sliding planes (e.g. Marques, 2003). The size of toppling failures in sea cliffs also depends on the geometry of the slope and on the geotechnical properties of the rock masses. These control the depth of the notches carved by marine erosion at the cliff toe which is compatible with marginally stable conditions of the whole cliff, and also the distance to the top of the cliff at which the tension cracks develop (e.g. Marques, 1994).

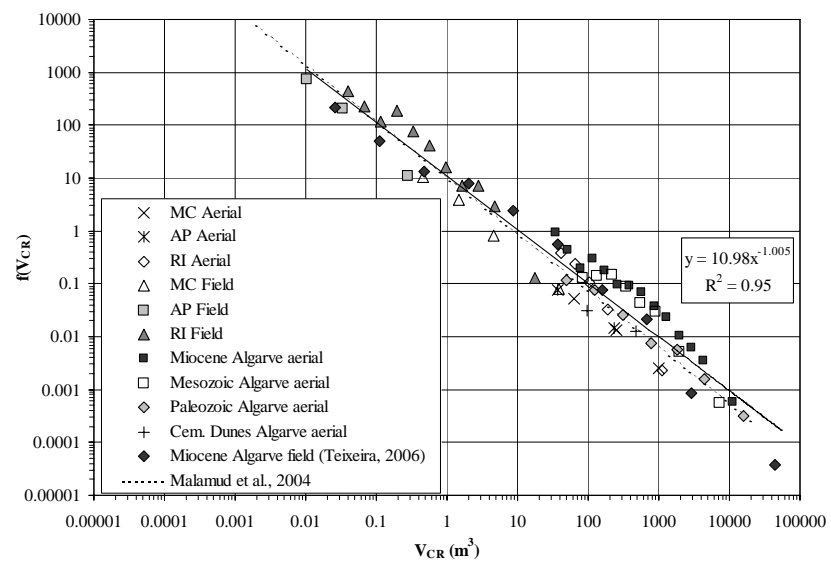

Fig. 9. Relation between volume displaced by cliff instabilities and the frequency density, with best fit inverse power law for all the data set.

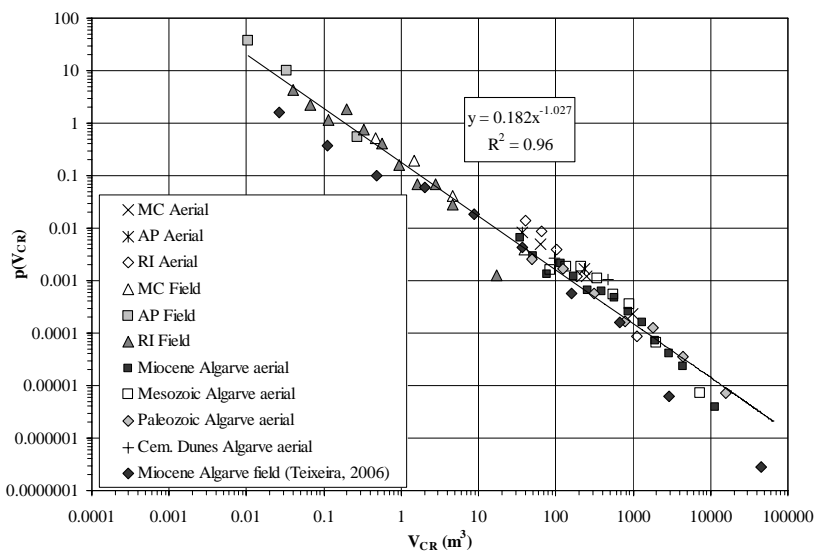

Fig. 10. Relation between volume displaced by cliff instabilities and the normalised frequency density, with best fit inverse power law for all the data set.

\section{Conclusions}

Systematic inventories of failures of low retreat rate sea cliffs, carried out in different geological and geomorphological conditions in the coast of Portugal and Morocco, covering a wide size range of the movements, from small $\left(\mathrm{V}<0.01 \mathrm{~m}^{3}\right)$ to comparatively large rockslides, topples and rockfalls $\left(\mathrm{V}>10^{4} \mathrm{~m}^{3}\right)$, at different time scales, provided magnitude-frequency relationships for horizontal area and volume displaced of the cliff failures that are well expressed by inverse power laws of the form $p=a \cdot x^{-b}$, with a near constant exponent $b=1.0$. This exponent is similar to those that have been found for rockfalls, suggesting similarities of processes and mechanisms involved. The normalised frequency densities show also small variations of the $a$ values, from 0.2 to 0.3 . 
For maximum local retreat at the cliff top the magnitudefrequency relations follows a less constrained inverse power law but only for retreat events larger than $2 \mathrm{~m}$. Smaller movements showed a diverging behaviour, with frequencies lower than the power law for larger movements. The explanation for this behaviour is not clear, because amalgamation of data seems not very significant in the type of data sets used, and the under sampling or incompleteness of the inventories for the smaller movements, was not accompanied by a similar behaviour in the area and volume magnitude-frequency relationships.

More substantially complete inventories obtained in different geological and geomorphological settings are required to confirm the magnitude-frequency behaviour of failures in strong, low retreat rate cliffs, including the influence of the different magnitude indexes considered (local retreat, area or volume).

Although requiring further confirmation, the power laws obtained may be useful to define the magnitude component of sea cliff retreat hazard assessment, considering that the data used in this study was obtained in a wide range of natural conditions. The full assessment of this natural hazard requires also that reliable models are obtained for the spatial and time distributions of cliff failures.

Acknowledgements. The author thanks Sebastião Teixeira for kindly providing one of the inventory data sets used in this study and to Bruce Malamud for helpful discussions. Prof. Rory Mortimore and two anonymous referees are also acknowledged for their useful comments.

Edited by: J.-P. Malet

Reviewed by: R. Mortimore and two other anonymous referees

\section{References}

Andrade, C., Freitas, M. C., Moreno, J., and Craveiro, S. C.: Stratigraphical evidence of Late Holocene barrier breaching and extreme storms in lagoonal sediments of Ria Formosa, Algarve, Portugal. Mar. Geology, 210, 339-362, 2004.

Anonymous: Anuário Sismológico de Portugal, Instituto Nacional de Meteorologia e Geofísica, Lisbon, 1947-2003 (in Portuguese).

Antunes, M. T., Bizon, G., Nascimento, A., and Pais, J.: Nouvelles donnés sur la datation dês depôts miocènes de l'Algarve, Ciências da Terra (UNL), 6, 153-168, 1981.

Brardinoni, F. and Church, M.: Representing the landslide magnitude-frequency relation: Capilano River basin, British Columbia, Earth Surf. Proc. Land., 29, 115-124, 2004.

Catalão, J., Catita, C., Miranda, J. M., and Dias, J. A.: Photogrammetric analysis of the coastal erosion in the Algarve (Portugal), Géomorphologie: relief, processus, environnement, 2, 119-126, 2002.

Correia, F., Dias, J. M. A., and Boski, T.: The retreat of eastern Quarteira cliffed coast and its possible causes (preliminary results), Gaia, 9, 119-122, 1994.
Chau, K. T., Wong, R. H. C., Liu, J., and Lee, C. F.: Rockfall Hazard Analysis for Hong Kong Based on Rockfall Inventory, Rock Mech. Rock Eng., 36(5), 383-408, 2003.

Dai, F. C. and Lee, C. F.: Frequency-volume relation and prediction of rainfall-induced landslides, Eng. Geol., 59, 253-266, 2001.

Dong, P. and Guzzetti, F.: Frequency-size statistics of coastal softcliff, J. Waterway, Port, Coastal Eng., 131(1), 37-42, 2005.

Dussauge-Peisser, C., Helmstetter, A., Grasso, J.-R., Hantz, D., Desvarreux, P., Jeannin, M., and Giraud, A.: Probabilistic approach to rock fall hazard assessment: potential of historical data analysis, Nat. Hazards Earth Syst. Sci., 2, 15-26, 2002, http://www.nat-hazards-earth-syst-sci.net/2/15/2002/.

El Alami, S. O., Tadili, B., Ait Brahim, L., and Mouayn, I.: Seismicity of Morocco for the period 1987-1994, Pure Appl. Geophys., 161, 969-982, 2004.

Guzzetti, F., Carrara, A., Cardinali, M., Reichenbach, P., Galli, M., and Ardizzone, F.: Landslide hazard evaluation: an aid to a sustainable development, Geomorphology, 31, 181-216, 1999.

Guzzetti, F., Malamud, B. D., Turcotte, D. L., and Reichenbach, P.: Power-law correlations of landslide areas in central Italy, Earth Plan. Sci. Lett., 195, 169-183, 2002.

Guzzetti, F., Reichenbach, P., Cardinali, M., Galli, M., and Ardizzone, F.: Probabilistic landslide hazard assessment at the basin scale, Geomorphology, 72, 272-299, 2005.

Lee, E. M., Hall, J. W., and Meadowcroft, I. C.: Coastal cliff recession: the use of probabilistic prediction methods, Geomorphology, 40, 253-269, 2001.

Lee, E. M., Meadowcroft, I. C., Hall, J. W., and Walkden, M.: Coastal landslide activity: a probabilistic simulation model, B. Eng. Geol. Environ., 61, 347-355, 2002.

Hall, J. W., Meadowcroft, I. C., and van Gelder, P. H. A. J. M.: Stochastic simulation of episodic soft coastal cliff recession, Coast. Eng., 46, 159-174, 2002.

Hovius, N., Stark, C. P., and Allen, P. A.: Sediment flux from a mountain belt derived by landslide mapping, Geology, 25, 231234, 1997.

Hovius, N., Stark, C. P., Hao-Tsu, C., and Jinn-Chuan, L. J.: Supply and removal of sediment in a landslide-dominated mountain belt: Central Range, Taiwan. J. Geol., 108, 73-89, 2000.

Hungr, O., Evans, S. G., and Hazzard, J.: Magnitude and frequency of rock falls along the main transportation corridors of southwestern British Columbia, Can. Geotech. J., 36, 224-238, 1999.

Iwahashi, J., Watanabe, S., and Furuya, T.: Mean slope-angle frequency distribution and size frequency distribution of landslide masses in Higashikubiki area, Japan, Geomorphology, 50, 349364, 2003.

Keefer, D. K.: Landslides caused by earthquakes, Geol. Soc. Am Bull., 95, 406-421, 1984.

Malamud, B. D., Turcotte, D. L., Guzzetti, F., and Reichenbach, P.: Landslide inventories and their statistical properties, Earth Surf. Proc. Land., 29, 687-711, 2004.

Marques, F. M. S. F.: Sea cliff evolution and related hazards in miocene terranes of Algarve (Portugal), 7th. Int. Cong. of the I.A.E.G., 5-9 Sep 1994, Lisbon. Proc., A. A. Balkema, Vol. 4, 3109-3118, 1994.

Marques, F. M. S. F.: The sea cliffs of the coast of Algarve. Dynamics, processes and mechanisms. PhD thesis, University of Lisbon, 556 pp., 1997 (unpublished, in Portuguese).

Marques, F. M. S. F.: Landslide activity in Upper Paleozoic shale 
sea cliffs: a case study along the western coast of the Algarve (Portugal), B. Eng. Geol. Environ., 62(4), 299-313, 2003.

Marques, F. M. S. F.: A simple method for the measurement of cliff retreat from aerial photographs, Z. Geomorphol. - Supplementbände, 144, 39-59, 2006a.

Marques, F. M. S. F.: Rates, patterns and timing of cliff retreat. A case study on the west coast of Portugal, Z. Geomorphol. Supplementbände, 144, 231-257, 2006 b.

Marques, F. M. S. F., Aberkane, M., and Azevedo, T. M.: Le recul des falaises cotiéres de Larache: donnés préliminaires. Deuxième rencontre des quaternaristes Marrocains, 26-28 Sep, Errachidia, Maroc. Proc. P., Fac. Sciences Tech. Errachidia, Maroc, 15-17, 2003.

Marques, F. M. S. F. and Romariz, C.: Preliminary note on sea cliff retreat, 4 Cong. Nac. Geotechnics, 2-4 Oct, Lisbon. Proc., 1, Port. Soc. Geotechnique, Lisbon, 57-66, 1991 (in Portuguese).

Marques, F. M. S. F. and Andrade, C.: Discussion of: Dias, J. M. A. and Neal, W. J. (1992) Sea cliff retreat in southern Portugal: profiles, processes, and problems, J. Coast. Res., 9(4), 1129-1135, 1993.

Moore, L. J. and Griggs, G. B.: Long-term cliff retreat and erosion hotspots along the central shores of the Monterey Bay National Marine Sanctuary, Mar. Geol., 181, 265-283, 2002.

Pelletier, J. D., Malamud, B. D., Blodgett, T., and Turcotte, D. L.: Scale-invariance of soil moisture variability and its implications for the frequency-size distribution of landslides, Eng. Geol., 48, 255-268, 1997.
Pires, H. O.: O Clima de Portugal. Alguns aspectos do clima de agitação marítima de interesse para a navegação na costa de Portugal, Instituto Nacional de Meteorologia e Geofísica (IM), Lisbon, 1989 (in Portuguese).

Ramalho, M. M., Rey, J., Zbyszewski, G., Alves, C. A. M., Almeida, F. M., Costa, C., and Kullberg, M. C.: Carta Geológica de Portugal na escala 1:50.000 and Notícia Explicativa da Folha 34-C Cascais, LNEG, Lisbon, 1981 (in Portuguese).

Rocha, R. B., Ramalho, M. M., Manuppella, G., Zbyszewski, G., and Coelho, A. V. P.: Carta Geológica de Portugal na escala 1:50 000 and Notícia Explicativa da Folha 51-B, Vila do Bispo, LNEG, Lisbon, 1979 (in Portuguese).

Ribeiro, A., Oliveira, J. T., Ramalho, M., Ribeiro, M. L., and Silva, L.: Carta Geológica de Portugal, na escala 1:50 000. Notícia Explicativa da folha 48-D, Bordeira, LNEG, Lisbon, 1987 (in Portuguese).

Stark, C. P. and Hovius, N.: The characterization of landslide size distributions, Geophys. Res. Lett., 28(6), 1091-1094, 2001.

Sunamura, T.: Geomorphology of Rocky Coasts, Wiley, New York, 302 pp., 1992.

Teixeira, S. B.: Slope mass movements on rocky sea-cliffs: A power-law distributed natural hazard on the Barlavento Coast, Algarve, Portugal, Cont. Shelf. Res., 26, 1077-1091, 2006.

Varnes, D. J.: Landslide Hazard Zonation: a Review of Principles and Practice, UNESCO Press, Paris, 63 pp., 1984.

Zbyszewski, G. and Almeida, F. M.: Carta Geológica de Portugal na escala 1:50.000 and Notícia Explicativa da Folha 30-C Torres Vedras, LNEG, Lisbon, 1955 (in Portuguese). 